\title{
Analysis of Family Clinical, vision of service nurses
}

\author{
Análise de uma Clínica da Família, visão dos enfermeiros do serviço \\ Análisis del una Clínica de Familia, la visión de las enfermeras de servicio
}

Daniele Merisio Raimundi', Francieli Furtado Ferreira² ${ }^{2}$ Fernanda Cristina Aguiar Lima ${ }^{3}$, Valeria de Carvalho Araújo Siqueira ${ }^{4}$

1,2,3,4 Universidade Federal de Mato Grosso. Faculdade de Enfermagem. Cuiabá, MT, Brazil.

\begin{abstract}
Objective: to know the practice of the Family Clinic in Cuiaba and its relationship with the precepts of the expanded clinic, from the perspective of the service nurses. Method: qualitative descriptive research, data collection with semi-structured interviews and results analyzed according to the method of thematic content analysis. Results: for nurses working in the service, this assumes a differentiated and innovative proposal, which seeks to correlate with shared management in its three spheres. Although most do not know the Enlarged Clinic term in his speech cited its main principles and its tools. The greatest potential described were related to the Support Center for Health and popular participation, and as challenges, the lack of community health worker, the national health establishment registration and the difficulty of operation due to the profile of the professionals technical level arising from secondary care. Conclusion: The clinic has positive aspects that can contribute to the advancement of the profession, to train health professionals and an innovative primary care model. Therefore, it emphasizes the need for implementation of continuing education in order to realize its proposal, and further studies on site.
\end{abstract}

DESCRIPTORS

Nursing; Primary Health Care; Family Health Strategy; Humanization of Assistance; Comprehensive Health Care.

Correspondence Addressed to: 


\section{INTRODUCTION}

Regulated by Law No. 8.080 of September $19^{\text {th }}, 1990$ and considered one of the largest public health systems in the world, the Unified Health System (SUS) in Brazil is characterized as an ongoing process, so there is often need for consolidation of their principles and guidelines in order to inspire tools and to strengthen policies, as it seeks to integrate and coordinate actions in the municipal, state and federal spheres ${ }^{(1)}$.

In this sense, the National Policy of Humanization (NHP) of Care and Management of SUS, or Humaniza SUS as it is also known, is one of the strategies established in order to strengthen and improve the care process, managing the relationships between managers, workers and users $^{(2)}$. Thus, it foresees the use of essential tools, among them the Expanded and Shared Clinic, whose main objective is to promote the autonomy of the health service user. It treats the subject-family-community as a whole (biopsychosocial being) in their life context, seeking thereby a transdisciplinary and multidisciplinary care, in view of the subject as a co-responsible and active being who is autonomous in the health-disease process ${ }^{(2)}$.

Through the incorporation of the NHP principles in the context of primary care, it is believed that the relevance of Expanded and Shared Clinic is enhanced to an extent that enables the active participation of subjects, and consequently their autonomy in health and disease process, contributing to the scope of the resoluteness for this level of care ${ }^{(2)}$.

Extending the view beyond the clinical aspects involves designing health in an extended form, not restricted to biomedical care, but, assuming quality of life and autonomy of the subject. Thus, taking into consideration the care to the user in their social context, in order to promote health and prevent diseases, with a view beyond the epidemiological, biological, sociocultural, individual, collective, psychological and spiritual aspects ${ }^{(2)}$.

Given these precepts and considering the need to reformulate the way we make health, the Family Clinic (FC) is an innovative proposal in Brazil, promoted by the Municipal Health Department and Civil Defense of Rio de Janeiro (SMSDC-RJ), and established based on the normative proposal of the Family Health Strategy (FHS), which concentrates five or more Family health teams. These health units, besides expanding the coverage of basic care in the city, were designed to increase the resoluteness of this level of care. Thus, they offer a differentiated service profile compared to other FHS, providing, for example, laboratory tests and image in $100^{(3)}$.

Considering its pioneering in the state and the implementation of one unit using this model in the city of Cuiabá, it is believed that an analysis of the service from the perspective of nurses who are part of the teams, tend to contribute to elucidate relevant issues in order to optimize health care. Thus, this study aims to understand the perspective of nurses that integrate the Family health teams, as the organization of practice in FC in the city of Cuiabá, and its relationship with the precepts of Expanded Clinic.

\section{METHODS}

This is a qualitative study, conducted by content analysis from the thematic theoretical framework. We sought to answer specific questions, being directed by the Social Sciences before a level of reality that is not amenable to quantification, that is, working with the universe of meanings, reasons, aspirations, beliefs, values and attitudes ${ }^{(4)}$.

The chosen unit was selected due to the fact that it represents a pioneering service in the state of Mato Grosso, organizing family health teams which share the same physical structure, hence the origin of the name - Family Clinic. It is import to highlight that the only Support Center for Family Health (NASF) of the city of Cuiabá works in this space.

Although the initial proposal is focused on primary care, some peculiarities are presented, in particular the fact that the unit at the time of the study, to be registered formally as polyclinic, and occupy the same physical structure where once worked this service. Allied to this is added also a negative point, the lack of professionals in the team planned to develop Family Health - the Community Health Worker (CHW).

Data collection involved all nurses working in the Family Clinic at the time of the study, for a total of five professionals. From October to November 2014 an individual interview to each nurse was applied, which were recorded and transcribed for later analysis. All professionals have expressed interest in participating in the research, however, the demand for services and schedules organized by the county Health Department (events and training), were determinants in some interviews that were often rescheduled.

In the pre-analysis phase, interviews were transcribed verbatim, thus allowing the initial reading of the material. The second phase consisted of detailed analysis of the selected material organized in thematic units, and a description of the characteristics relevant to the manifest content. Then the step of thematic categorization was performed, being composed by the group in units of meaning, with reference to the similarity of feelings of those present in the discourses of the subjects ${ }^{(4)}$. The participants discourse mentioned in the text, were identified by the initial $\mathrm{N}$ (nurse) and a successive number sequence $(\mathrm{N} 1, \mathrm{~N} 2, \ldots)$ in order to maintain the anonymity.

This study is part of a research entitled "The organization of work in the Family Health Strategy in view of the Expanded Clinic" approved by the Research Ethics Committee at the Hospital Universitário Júlio Muller, number 869608/2014. All FC nurses were invited to participate, and those who agreed, signed the Consent Form and were assured the confidentiality of information as well as privacy and anonymity, respecting, thus the Resolution No. 466 of 2012 from the National Health Council, which provides guidelines and regulations concerning research involving human subjects ${ }^{(5)}$. 


\section{RESULTS}

As mentioned above, the FC consists of five family health teams, thus, five nurses are currently working in the unit, one in each team. All agreed to participate in the research, so the data presented refer to the prospect of such professionals.

The results were organized into three categories of analysis, such as: Profile of nurses and their integration process in the Family Clinic; Family Clinic from the perspective of the service nurses; and the challenges and potential of the service.

\section{Profile of NURSes and their INTEgration IN the Family Clinic}

As shown in Table 1, among the professionals, most are female and are aged between 29 and 48 years. All nurses have 40 hours/week, as provided for professionals in the $\mathrm{FHS}^{(1)}$, and most have employment contract.
Table 1 - Profile of the Family Clinic nurses, in the city of Cuiaba. Mato Grosso, 2014.

\begin{tabular}{lcc}
\hline Characteristics & N & $\mathbf{\%}$ \\
\hline Gender & 04 & \\
Female & 01 & 20 \\
Male & & \\
Type of employment & 01 & 20 \\
Permanent & 04 & 80 \\
Temporary contract & & \\
Age & 01 & 20 \\
Up to 28 years & 02 & 40 \\
$29-38$ years & 02 & 40 \\
$39-48$ years & & \\
\hline
\end{tabular}

Regarding the aspects related to professional practice, Table 2 shows that most nurses have been integrated in the FC for less than a year, time of implantation, although they have a long experience in $\mathrm{PHC}$ and large professional experience. However, most of them do not have Specialist Certificate in the context where they work.

Table 2 - Characterization of the nurses according to training and professional practice in primary health care. Cuiaba, MT.

\begin{tabular}{ccccc}
\hline Subject & $\begin{array}{c}\text { Specialization Certificate } \\
\text { in PHC }\end{array}$ & $\begin{array}{c}\text { PHC experience time } \\
\text { (years) }\end{array}$ & $\begin{array}{c}\text { Time from graduation } \\
\text { (years) }\end{array}$ & $\begin{array}{c}\text { Working time in the FC } \\
\text { (months) }\end{array}$ \\
\hline E1 & No & 01 & 03 & 12 \\
E2 & No & 14 & 15 & 12 \\
E3 & No & 04 & 10 & 06 \\
E4 & Yes & 05 & 07 & 03 \\
E5 & Yes & 06 & 07 & 04 \\
\hline
\end{tabular}

All nurses, when questioned in relation to some kind of training or specific training to work in the FC, denied having had this experience: (in relation to specific clinic, no, but in relation to primary care, yes) (N3). Although four of the five nurses cited training relating to the FHS programs, one of them pointed out that even the introductory FC work was offered:

(we constantly have trainings, about all the programs, okay, the thing we do not have is an introductory training, (...) it hasn't happened yet, an introductory course, for none of the clinic staff) (N4).

\section{Practice In Service Related to the eXPanded Clinic}

We found several aspects in relation to the FC implementation purpose in the capital city of Mato Grosso, many report that it brings innovative and problem-solving strategy:

(Bringing health closer, right, you take health into the patient's home (...) to be close to those people who need direct care, treatment, prevention (N4)); (I think this is a great model (...) very interesting for us to be following in the most humane way (...) from the beginning we always had the view that it is a different unit (N1)); (It comes with the proposal to be closer and closer to the health care community, and the health service to the community (N2)).

Regarding the organization and work management, the discourses of FC nurses denote that there is connection with the precepts of the NHP, as reported and shared decisions are taken collectively after discussion in the spaces of multiple participation ${ }^{(25)}$.

FC Nurses realize the service organization as distinctive unit proposal, with shared management in its three spheres (materials management, people and care): each one manages their team and together we manage the clinic

\section{(...) we're reorganizing the structure, changing the logistics, readapting rooms, (...) for us to be working together (N5)); (... So we tried to put these areas in common with someone responsible and making rotation with the people who are within the sectors (N3)); (Now the team is planned with everyone, wi- th all the teams (...) I believe that with the five fami- ly health teams helping each other's, they gain (N2)).}

The FC has the differential clinical analysis laboratory and $\mathrm{x}$-ray working all day, resulting in a more rapid and targeted intervention needs of users. We also noted the importance of these instruments in the nurses discourses:

$$
\begin{aligned}
& \text { (the clinic also comes with the proposal, from the patient } \\
& \text { that can make } x \text {-ray, which is also a direct intervention, } \\
& \text { resoluteness and we have this service every day) (N3). }
\end{aligned}
$$

When asked about the association they make between the Family Clinic and the precepts of Extended Clinic, only one nurse could answer, even though he did not know the meaning of the Extended Clinic term, the others in the course of their discourses mentioned its precepts and its tools: 
(I believe that with all these aspects we just discussed, I believe we do in fact an extended care (N3)); (a whole care plan was designed, and we went there and applied it and it is being followed up, and in a little while here we will make evaluation of this care plan, because if it is not working, we have to change, right?" (N5)); (Before they sought us when they had something, not like today, consultations are scheduled, right, They can come, talk to the doctor, it is not a doctor visit, right (N2)); (I like to listen to patients, (...) first I need to hear what they have to say, what is their question, why they came to the clinic, you know? to see what I can do, How I can help them, or if I cannot help them, I will look for someone who can (N5)).

The various tools of the expanded clinic are dialogue, bonding, listening, matrix support (NASF support), the individual therapeutic project, in addition to the integral and humanized care are expressed by nurses, as we saw in the previous paragraph, one concludes that:

(Today we are well rewarded, we see how the bond we have with the patient, the recognition they feel that they have for us, they feel integrated within the unit, this is something they were not used to, so today we see this difference (N1)).

\section{The Challenges and opportunities of the Family Clinic}

Comparing the service where they are inserted to the other FHS units, nurses pointed out as a major difference the presence and support of NASF within the unit and the facilities it provides:

(we have this privilege, you know, within this phy-
sical structure here in the clinic, NASF has a room
here with us) (N2); (What ends up helping a lot here,
having a very good development due to NASF pro-
fessionals, we have a very good relationship at work)
(N1); (I can make interventions here, or request help,
or ask for guidance and I think it's different from
other units) (N3).

Other possibilities listed by nurses are the community radio, community participation and district presidents in the management board, waiting room and groups, such as Hiperdia. Thus, we can notice the importance given to community participation in FC actions, showing that nurses value the guidelines of SUS, in particular with regard to social control and collegiate bodies.

As challenges, most nurses highlighted: the lack of CHWs in the unit; the fact that the unit does not have a CNES related to PC service, because it is still registered as an institution of secondary care; and the difficulty of operation occurs due to the skills of technical level professionals, more focused on performance in secondary care.

The main challenge faced by the team was evidenced by the lack of CHW, as they are essential for the FHS to work properly:

(The big negative aspect is always the lack of community workers, who are our link to the community)
(N3); (The goals that we have to achieve (...) that comes back again is the lack of health worker, for example, we have to achieve our preventive tests goal (...) without them there is no way we have the right control) (N4); (We are not family bealth team (...) the lack of community health worker (...) they are the link to the community) (N2).

An unfavorable point also cited by participants, which hinders the performance of FC actions as well as health care for the family, would be the lack of service registration at CNES:

(All production is made here, it is fed into the register of secondary care and not the primary (...) it interferes in our reports that we have to send monthly) (N4). (We haven't got CNES yet (...) we are working for a year (...) performing actions of the family health team, but we are not a family health team) (N2).

Professionals pointed out as a factor that negatively interfere with their work process, the fact that most of the mid-level staff were previously entered in secondary care and have not received training focused on primary care, so some nurses believe that they do not have the profile to work in FC:

(So we have this great difficulty today, because of the worker profile (...) some people came from the secondary care, which was the former polyclinic, and now they are integrated in the family clinic) (N2). In this sense, we realize that nurses are seeking to empower their team to the specific care of primary care. (They were not trained (...) this is another negative point here of the techniques (...) I gave a FHS lesson these days that lasted the whole afternoon (...) I am teaching them gradually) (N5).

\section{DISCUSSION}

\section{Profile of nURSes and their integration in the FAmily Clinic}

The analysis about the profile of nurses working meets the findings of Costa et al. ${ }^{(6)}$, showing that the primary health care workers are mostly women between 23-55 years of age. Studies show that, on average, in the FHS, the proportion of women and younger workers is greater. In this sense, the literature also points out that, in more than 45 years, the physical and mental capacity decays with time; now young people are not so professional mature ${ }^{(7-8)}$.

An important factor to be considered refers to the lack of permanent professionals, which can represent a disadvantage for the services, as they do not feel safe at work and there is great instability in the bond, which can affect negatively the practices ${ }^{(9)}$.

It is important to note that safety at work interferes directly and positively the actions carried out by the nurse professional. Once the professional has a permanent bond, he/she shows more autonomy to make changes in the ser- 
vice management mode, in assisting and even in the health unit routine.

Nurses reported different ways of inserting FC, such as curriculum analysis by the Municipal Health Department (MHD), transfer and exchange. Evidence that point to the fact, in the context of the FHS, the minority of professionals are inserted through public test and most have contracts $^{(9,10)}$. In this regard, it is believed that conflicts among professionals may become a reality, since there is often a difference of work and financial and professional stability. Thus, there is the need for a selection process via public test.

It is believed that there is a need of a more rigorous selection process of professionals in Primary Care (PC), whereas the profile of this level of attention has specific peculiarities compared to other services ${ }^{(11)}$. In it, the care, the bond and the humanization of general practices become more evident and necessary for the success of actions and monitoring of users. The selection of professionals to respond to this demand tends to contribute to greater resolution practices; Furthermore, it also highlights the need for training of those already in service, to reach the goal of changing habits and improve the management ${ }^{(12)}$.

As this is a health promotion service and disease prevention, professionals must be adequately qualified to better meet the demands of the community. In this case, it is noteworthy that both the service time as the training of nurses can contribute to the professional maturity and scope of the quality. However, most of them do not have specific training to work in $\mathrm{FH}$, which the training does not always prepare them for it.

With regard to specialization Certificate in $\mathrm{PC}$ area, this study is consistent with research ${ }^{(12-13)}$ in which it was found that most nurses inserted in the PC had certificates, but not specific to PC or Family Health.

Considering the proposed model for this level of care, based on the preventability of diseases through specific actions, specializations and professional development are of great importance to provide higher quality and resoluteness in the service, as well as the implementation of humanized care.

It is considered that the specific training to work in PC does not meet alone the distinct needs of this area. Therefore, the permanent education service is indispensable in order to direct practices in accordance with them.

Given the discourses, professionals seek qualification through the training that the SMS offers, with emphasis on FHS programmatic actions, involving vaccine room, women's health, children's health, leprosy and tuberculosis. These qualifications offered by the institution are made possible through continuing education. However, today we have the need to develop lifelong learning, focused on the local problematic.

Silva ${ }^{(14)}$ points out that there is a need to study the reality of Basic health Units (BHU) users and technical-scientific update for professionals. In the study ${ }^{(15)}$, he supports the creation and maintenance of permanent education spaces in health for nurses to learn about their clinical work, which should be built in view of the extended clinic.

According to Castro and Campos ${ }^{(16)}$, in order to promote change investments in innovative methods in training of health professionals are necessary, aiming at their practices and experiences in the search for questioning the reality, first to seek its transformation. So, we have a primary tool to consolidate the National Policy of Permanent Education in Health, which appeared in 2009 in order to expand the reflection on health actions and in the care context $^{(17-18)}$.

With SUS humanization proposal and expanded clinic tool, a way to apply them to the FC must be considered in order to allow the use of such proposals and tools for the professionals who work there. In the nurses' discourses, we see the desire to train technicians for the specific primary care with humane care, since most were from secondary care, and dialogue with the people in the waiting room and groups, about this new FHS model that is the FC.

It is assumed that the previous training of all professionals involved in FC is essential, especially since it was designed by the municipal management as a model of innovation in PC and also as a teaching and research field, which is why there is, on site, many scholars and residents. Overall, it has been the objective of the institution in a model of excellence in primary care and academic training. All of this in order to contribute to the advancement of the profession, better resolution in the service and quality of care $^{(13,19)}$.

From this point of view, we see continuing education as essential in this new model, so that might allow us for a full health care as well as personal and professional development of those involved in the FC.

\section{Practice IN THE SERVICE RELATED TO THE EXPANDED CLINIC}

Through the view of service nurses, we suggest that this health care model is leading to better quality of care provided to the community, especially because it is an assistance area that was not attended by PC. According to the stu$\mathrm{dy}, 2012^{(20)}$, the expanded clinic comes as a facilitator for comprehensive care, requiring a rethinking of the technical organization of work, thus, enabling proper support to establish a bond with the community attended. And that access for that user at the facility, should be determined by resoluteness of the actions provided to the type of user health problem ${ }^{(21-23)}$.

We have also seen, through the discourses of the nurses in the $\mathrm{FC}$ who, in a way, have been fulfilling their role to mitigate the damage and working the expectations of users seeking health services in order to extinguish the notion of health as a product seeking rather than quantity, the quality of service ${ }^{(2)}$. In this same direction, Lima et al. ${ }^{(24)}$, in a study conducted in a BHU of Sao Paulo, revealed the perception of workers on issues involving the humanization, bonding, listening, integrality of care and centered on the individual.

This service model establishes the need for learning new techniques and teaching skills by workers and managers, so as to put them into practice. For integrality of care is a collective learning, and is fundamental to rethink the 
process and tools of work, so that increasingly professional practice approach of integrality of care $25,2,16)$.

It is noticed that a pedagogical change is essential for such precepts to have effects on personal and professional lives of members of the FC team, as this change in practice requires a transformation in acting and thinking in order to incorporate it into service to all members of the team, which also requires a change in working routine and continuing education.

In this sense, Peduzzi et al. ${ }^{(26)}$ highlight the importance of communication in teamwork, and positive results arising from coordinating multidisciplinary practice towards a single goal. Thus, for such health care model to be effective and decisive, it is important to emphasize the professional-user-manager correlation, since everyone is involved in this process. In addition, for this method to succeed, Castro and Campos ${ }^{(16)}$ based on the assumption that we need to instigate subjective of each of the professionals involved, as they are the key to success on care services.

In this category we sought to analyze the view that nurses entered the clinic have about this service, as the importance of knowing this, because knowing this fact is essential to develop the work satisfactorily, effectively and positively. We have seen that even those who realize the $\mathrm{FC}$ as an innovative strategy, resoluteness and differentiated both in care aspects as well as their shared management proposal. The Extended Clinic term is not yet known by professionals, but they cite many of its premises that may denote the need for further updating and strengthening of policies proposed by SUS, such as FC.

\section{The Challenges and opportunities of the Family Clinic}

Considering that NASF was created with the intention of increasing the resolution and the scope of the FSH actions, through the matrix of support to professionals of $\mathrm{PHC}$, the multidisciplinary team composition enables the achievement of these goals, sharing technology and knowledge according to community demands needs ${ }^{(1)}$. Thus, we note that the clinic nurses demonstrate an ethical commitment to the subject, which is seen in a unique way, as they assume responsibility for service needs, making use of NASF support when it is not within their ability to performance, focusing on collective service.

Nurses highlighted this interaction with the multidisciplinary team of NASF in emphasizing this partnership in home visits, shared consultations and family planning. This suggests that, to some extent, NASF has been fulfilling its role of matrix support. Thus, we see the importance of this exchange among professionals so that the proposal of the clinic is enabled and it is also worth highlighting the bonds that are created between the user-service, resulting in incentive for staff to provide quality of care and seek a positive partnership ${ }^{(26)}$.

We can say that the discourses of participants reinforce something that was proposed in the study of Rosa, Pelegrini and Lima ${ }^{(22)}$, who claim the need to reorganize the process of working through community involvement in the planning of actions in order to trace interventions more assertive, and corresponding to the needs and expectations of it. Such capabilities are associated with the proposal of the clinic is to be a model in health care and community participation.

Thus, the CHW's absence triggers other challenges, such as: the lack of users' registration and updating of these entries; difficulty in disseminating health actions and campaigns, guidance on the operation of the FC; besides this be the link to the service and community, and the main health vigilant.

CHW have a key role in PC in order to enable integration between service-community, monitoring of individuals and communities, in order to register and update data, and inform the staff about the risk situations. They are closer to the community, has the ability to assist in the implementation and development of health actions, promoting and strengthening such actions, considering the local singularities ${ }^{(1,27-30)}$.

Costa et al. ${ }^{(28)}$ concluded in their study that the $\mathrm{CHW}$ work in PC, is of great significance for the implementation of the FHS and consolidation of the expanded concept of health, because they perform different activities in the community, making a commitment to articulate the principles and health actions.

The lack of registration service in the CNES, we can point out the contrary interference to the objectives of the FHS as it is through the real knowledge of the health care network and professionals, as well as the appropriate financial transfers to the establishment. Thus their lack entails the dissemination of outdated information, difficulty of implementation of regulatory complexes, in addition to non-financial transfer, considering also that the correct update of CNES is essential for health professionals decision-making ${ }^{(29)}$.

Importantly, the lack of registration of families invalidates both the establishment of goals to be achieved, as the monitoring of health actions taken, which may negatively impact the transfer of funds, materials and instruments.

In the case of training to work in primary care, the view of nurses corroborates the study conducted in a city of $\mathrm{Pa}-$ raná State, with PC professionals, where it was found that to work in the FHS beyond the capabilities offered by the health department, the professionals should have the profile to work in this area ${ }^{(35)}$. Being the responsibility of the Ministry of Health to articulate ways, with the Ministry of Education for the training of professionals, to meet this demand ${ }^{(1)}$.

Thus, we believe that, with regard to the difficulties related to the management of health, the absence of $\mathrm{CHW}$ and registration services in the unit as primary care, requires immediate strategies to regularize the service and direct practices to obtain the desired results for this level of attention, it is believed that the public tests for contracting CHW represents a strategy that will trigger the resolution of other problems, enabling the registration of the unit.

Regarding the profile of mid-level professionals, pointed by some nurses as negative, we believe that there is possibility of resolution in loco, as nurses develop educatio- 
nal practices with this public, moreover, we emphasize the importance of permanent education, in order to drive the solution not only for this problem but several aspects, thus seeking a more extensive humanized and quality care, truly focused on community needs.

\section{CONCLUSION}

It was found that the view of the study subjects is of a different service and more resolute when compared with others of the same level of attention, resulting in benefits and satisfaction to the population cared. It was also noted that the health unit has potential to be encouraged and improved, but there are still limitations to be discussed and worked on.

Although this view of nurses on the FC is not sufficient to understand how things are being effective developed, which would require the observation practice among other ways of approaching the topic, the findings of the research are indicative of how things are being developed at the moment. Similarly, the study suggests potential and challenges related to the implementation of the $\mathrm{FC}$ to be considered, so that it becomes better.

This category of analysis leads us to the positive aspects related to practices of health care improvement to the enrolled population, and various tools and foundations of NHP and Extended Clinic are highlighted on the nurse's view. Since the matrix support offered by NASF and the interaction it has with the BHU teams was a great exposure potential. This is a rich result, seen how important this interaction is to provide quality, humane, comprehensive and resolute care.

We also note that as teaching and research field, the FC contributes to the training of professional nurses facing an innovative primary care, being a health promotion model and prevention of health and care for the state of Mato Grosso, so this model brings the nurse as the leading actor management and thus co-author of the necessary changes.

It is considered that the CHW professional regulation is primarily needed in the clinic so that he/she can carry out and implement its proposal, which is to be a model of care, teaching and research, the first two challenges are actually a chain of reaction, as it has the same CNES as primary care, if they do not have CHW. The third, which is the profile of technical professionals, has been partly solved, since the problem was detected and some nurses are seeking to empower the team.

Thus, we learn how important the assessment of how things are being developed in fact in this innovative strategy and whether it is following what is recommended by the Ministry of Health, around which other studies should be followed. Furthermore, an ongoing clinical education project is suggested to be implemented, in order to achieve the changes necessary to manage care and the demands of service, aimed at Expanded Clinic.

\section{RESUMO}

Objetivo: conhecer a prática da Clínica da Família em Cuiabá e sua relação com os preceitos da clínica ampliada, sob a perspectiva dos enfermeiros do serviço. Método: pesquisa descritiva qualitativa, coleta de dados com entrevista semi-estruturada e resultados analisados segundo o método de análise de conteúdo do tipo temática. Resultados: para os enfermeiros atuantes no serviço, este assume uma proposta diferenciada e inovadora, no qual busca se correlacionar com a gestão compartilhada em suas três esferas. Apesar de a maioria não conhecer o termo Clínica Ampliada em suas falas citaram seus principais preceitos e suas ferramentas. As maiores potencialidades descritas foram a relação com o Núcleo de Apoio à Saúde da Família e a participação popular, e como desafios, a falta de agente comunitário de saúde, do cadastro nacional de estabelecimento de saúde e a dificuldade de atuação devido ao perfil dos profissionais de nível técnico advindos da atenção secundária. Conclusão: a clínica possui aspectos positivos que podem contribuir para o progresso da profissão, para a formação de profissionais da saúde e para um modelo de assistência de nível primário inovador. Logo, enfatiza-se a necessidade de implantação da educação permanente com o objetivo de concretizar sua proposta, além de estudos posteriores no local.

\section{DESCRITORES}

Enfermagem; Atenção Primária à Saúde; Estratégia Saúde da Família; Humanização da Assistência; Assistência Integral à Saúde.

\section{RESUMEN}

Objetivo: conocer la práctica de la Clínica Familiar en Cuiaba y su relación con los preceptos de la clínica ampliada, desde la perspectiva de las enfermeras de servicio. Método: investigación descriptiva cualitativa, la recopilación de datos con entrevistas y resultados semiestructuradas analizadas según el método de análisis de contenido temático. Resultados: para las enfermeras que trabajan en el servicio, esto supone una propuesta diferenciada e innovadora, que busca que se correlaciona con la gestión compartida en sus tres esferas. Aunque la mayoría no sabe el término Clínica ampliada en su discurso citó sus principios y sus herramientas. El mayor potencial descrito se relaciona con el Centro de Apoyo a la Salud y la participación popular, y como desafíos, la falta de personal de salud de la comunidad, el registro nacional de establecimientos de salud y la dificultad de la operación debido al perfil de los profesionales nivel técnico derivado de la atención secundaria. Conclusión: La clínica cuenta con aspectos positivos que pueden contribuir al avance de la profesión, para capacitar a profesionales de la salud y un innovador modelo de atención primaria. Por lo tanto, se hace hincapié en la necesidad de implementación de la educación permanente, para darse cuenta de su propuesta, y estudios adicionales en el lugar.

\section{DESCRIPTORES}

Enfermería; Atención Primaria de Salud; Estrategia de Salud Familiar; Humanización de la Atención.; Atención Integral de Salud. 


\section{REFERENCES}

1. Brasil. Ministério da Saúde; Secretaria de Atenção à Saúde, Departamento de Atenção Básica. Política Nacional de Atenção Básica. Brasília; 2012a.

2. Brasil. Ministério da Saúde; Secretaria de Atenção à Saúde, Política Nacional de Humanização da Atenção e Gestão do SUS. Clínica ampliada e compartilhada. Brasília: Ministério da Saúde; 2009a. 64 p.

3. Harzheim E, organizador, Lima KM, Hauser L. Pesquisa avaliativa sobre aspectos de implantação, estrutura, processo e resultados das Clínicas da Família na cidade do Rio de Janeiro. [Porto Alegre]: Universidade Federal do Rio Grande do Sul; 2013.91 p. [Acesso em: 26 jan 2015]. Available from: http://www.sbmfc.org.br/media/file/Pesquisa $\% 20$ Avaliativa $\% 20$ sobre $\% 20$ aspectos $\% 20$ de $\% 20 \mathrm{implanta-}$ cao- $\% 2$ estrutura- $\% 20$ processo $\% 20 \mathrm{e} \% 2$ resultado $\% 2$ das $\% 2$ clinicas $\% 20$ de $\% 2$ familia $\% 20$ na $\% 20$ cidade $\% 20$ do $\% 20$ Rio $\% 20$ de $\% 20$ Janeiro\%20(2).pdf

4. MINAYO, MCS. O desafio do conhecimento: pesquisa qualitativa em saúde. 12th ed. São Paulo (SP): Hucitec; 2010.

5. Brasil, Conselho Nacional de Saúde, Resolução n. 466, de 12 de dezembro de 2012. Dispõe diretrizes e normas regulamentadoras de pesquisas envolvendo seres humanos. Diário Oficial da União nº 12, Brasília, 13 jun. 2013. Seção 1, p. 59.

6. Costa S, Prado M, Andrade T, Araújo E, Silva-Junior W, Gomes-Filho Z, Rodrigues C. Professional profile of healthcare providers holding university degree in Family Health Strategy teams in Montes Claros, Minas Gerais, Brazil. Revista Brasileira de Medicina de Família e Comunidade [Internet]. 2013 Abr 11; [citado 2015 Nov 26]; 8(27): 90-96. Available from: http://www.rbmfc.org.br/rbmfc/article/ view/530/552.

7. Martinez MC, Latorre MRDO, Fischer FM. Work ability: a literature review. Ciênc. saúde coletiva [Internet]. 2010 [cited 2014 Nov 27]; 15(Suppl 1): 1553-1561. Available from: http://www.scielo.br/pdf/csc/v15s1/067.pdf.

8. Hilleshein EF, Souza LM, Lautert L, Paz AA, Catalan V, Teixeira MG, Mello T. Capacidade para o trabalho de enfermeiros de um hospital universitário. Rev. Gaúcha Enferm. (Online) [Internet]. 2011 [cited 2015 Feb 16]; 32(3): 509-515. Available from: http://www.scielo.br/ pdf/rgenf/v32n3/11.pdf.

9. Carvalho BG, Peduzzi M, Ayres JRCM. Conceptions and typology of conflicts between workers and managers in the context of primary healthcare in the Brazilian Unified National Health System (SUS). Cad. Saúde Pública [Internet]. 2014 [cited 2015 Nov 26]; 30(7):14531462. Available from: http://dx.doi.org/10.1590/0102-311X00134613.

10. Junqueira TS, Cotta RMM, Gomes RC, Silveira SFR, Siqueira-Batista R, Pinheiro TMM, Sampaio RF. Labor relations under decentralized health management and dilemmas in the relationship between work expansion and casualization in the Brazilian Unifi ed National Health System. Cad. Saúde Pública [Internet]. 2010 [cited 2014 Nov 28]; 26 (5): 918-928. Available from: http://www.scielo.br/pdf/ csp/v26n5/14.pdf.

11. Barbosa SP, Elizeu TS, Penna CMM. The perspective of health professionals on access to Primary Health Care. Ciênc. Saúde Coletiva [Internet]. 2013 [cited 2015 Feb 19]; 18 (8): 2347-2357. Available from: http://www.scielo.br/pdf/csc/v18n8/19.pdf.

12. Corrêa ACP; Araújo EF, Ribeiro AC, Pedrosa ICF. Sociodemographic and professional profile of primary health care nurses in Cuiabá Mato Grosso. Rev. Eletr. Enf. [Internet]. 2012 [cited 2014 Oct 15] 14(1):171-178. Available from: http://www.fen.ufg.br/revista/v14/n1/ pdf/v14n1a20.pdf.

13. Silva JAM, Ogata MN, Machado MLT. Training of health workers on the primary health care: impacts and perspectives. Rev. Eletr. Enf. [Internet]. 2007 [cited 2014 Dec 16]; 9(2): 389-01. Available from: https://www.fen.ufg.br/revista/v9/n2/v9n2a08.htm.

14. Silva JAM, Peduzzi M. Work Education in Primary Health Care: interfaces between permanent education in health and the communicative action. Saúde Soc. [Internet]. 2011 [ cited 2015 Nov 26];20(4): p.1018-1032. Available from: http://www.revistas.usp.br/sausoc/ article/view/29736/31613.

15. Matumoto S, Fortuna CM, Kawata LS, Mishima SM, Pereira MJB. Nurses' Clinical Practice in Primary Care: a Process Under Construction. Rev. Latino-Am. Enfermagem [Internet]. 2011 [cited 2015 Nov 29]; 19(1): 123-130. Available from: http://www.scielo.br/pdf/rlae/v19n1/ pt_17.pdf.

16. Castro CP, Campos GWS. Paideia institutional support as a strategy for continuous education in health [Internet]. 2014 [cited 2015 Feb 07]; 12 (1): 29-50. Available from: http://www.scielo.br/pdf/tes/v12n1/03.pdf.

17. Brasil. Ministério da Saúde; Secretaria de Gestão do Trabalho e da Educação na Saúde, Departamento de Gestão da Educação em Saúde. Política Nacional de Educação Permanente em Saúde. Brasília: Ministério da Saúde; 2009b. 64 p.

18. Gomes KO, Cotta RMM, Mitre SM, Batista RS, Cherchiglia ML. O agente comunitário de saúde e aconsolidação do Sistema Único de Saúde: reflexões contemporâneas. Physis [Internet]. 2010 [cited 2015 Feb 21] ; 20( 4 ): 1143-1164. Available from: http://www.scielo. br/pdf/physis/v20n4/a05v20n4.pdf.

19. Oliveira FMCSN, Ferreira EC, Rufino NA, Santos MSS. Continuing Education and the Quality of Health Care: Meaningful Learning in Nursing Practice. Aquichán [serial on the Internet]. 2011 [cited 2015 Jan 25] ; 11(1): 48-65. Available from: http://www.scielo.org.co/ pdf/aqui/v11n1/v11n1a05.pdf.

20. Bonfada D, Cavalcante JRLP, Araújo DP, Guimarães J. Comprehensive health care as the core concept for technological organization in services. Ciênc. Saúde Coletiva [Internet]. 2012 [cited 2014 Dec 13]; 17 (2): 555-560. Available from: http://www.scielo.br/pdf/csc/ v17n2/a28v17n2.pdf.

21. Campos RTO, Ferrer AL, Gama CAP, Campos GWS, Trapé TL, Dantas DV. Assesment of quality of access in primary care in a large Brazilian city in the perspective of users. Saúde debate [Internet]. 2014 [cited 2014 Dec 12] ; 38 (spe): 252-264. Available from: http://www. scielo.br/pdf/sdeb/v38nspe/0103-1104-sdeb-38-spe-0252.pdf.

22. Rosa RB, Pelegrini AHW, Lima MADS. Resolutividade da assistência e satisfação de usuários da Estratégia Saúde da Família. Rev. Gaúcha Enferm. (Online) [Internet]. 2011 [cited 2015 Dec 15]; 32(2): 345-351. Available from: http://www.scielo.br/pdf/rgenf/v32n2/a19v32n2.pdf.

23. Brasil. Ministério da Saúde; Secretaria de Atenção à Saúde, Política Nacional de Humanização da Atenção e Gestão do SUS. Gestão participativa e cogestão. Brasília: Ministério da Saúde; 2009c. 56 p. 
24. Lima IFS, Lobo FS, Acioli KLBO, Aguiar ZN. Comprehensiveness according to the perception of Family Health Unit workers. Rev. Esc. Enferm. USP [Internet]. 2012 [cited 2015 Dec 11]; 46(4): 944-952. Available from: http://www.scielo.br/pdf/reeusp/v46n4/23.pdf.

25. Fracolli LA, Zoboli ELP, Granja GF, Ermel RC. The concept and practice of comprehensiveness in primary health care: nurses' perception. Rev. Esc. Enferm. USP [Internet]. 2011 [cited 2014 Jan 21]; 45(5): 1135-1141. Available from: http: http://www.scielo.br/pdf/reeusp/ v45n5/v45n5a15.pdf.

26. Peduzzi M, Carvalho BG, Mandú ENT, Souza GC, Silva JAM. Trabalho em equipe na perspectiva da gerência de serviços de saúde: instrumentos para a construção da prática interprofissional. Physis [Internet]. 2011 [cited 2015 Nov 19]; 21(2): 629-646. Available from: http://www.scielo.br/pdf/physis/v21n2/a15v21n2.pdf.

27. Lanzoni GMM, Cechinel C, Meirelles BHS. Agente Comunitário de Saúde: estratégias e consequências da sua rede de relações e interações. Rev Rene [Internet]. 2014 [cited 2015 Jan 29]; 15(1): 123-131. Available from: http://www.revistarene.ufc.br/revista/index.php/ revista/article/view/1492/pdf.

28. Costa SM, Araújo FF, Martins LV, Nobre LLR, Araújo FM, Rodrigues CAQ. Community health worker: a core element of health actions. Ciênc. saúde coletiva [Internet]. 2013 [cited 2014 Dec 10]; 18(7): 2147-2156. Available from: http://www.scielo.br/pdf/csc/v18n7/30. pdf.

29. Lira CS, Barbosa FES, Chaves LMF, Lima T MB, Silva GKF, Nogueira PTA, Santana MCC. Cadastro nacional de estabelecimentos de saúde como instrumento de auxílio na gestão: relato de experiência. Anais do $11^{\circ}$ Congresso Internacional da Rede Unida; 2014 [cited 2014 Dec 15]; Revista Interface - Comunicação, Saúde, Educação [online], supl. 3. [abstract]. Available from: http://conferencias.redeunida. org.br/ocs/index.php/redeunida/RU11/paper/view/3767

30. Lopes MCL, Marcon SS. Assistência à família na atenção básica: facilidades e dificuldades enfrentadas pelos profissionais de saúde. Acta Scientiarum. Health Sciences [Internet]. 2012 [cited 2015 Jan 27]; 34 (1): 85-93. Available from: http://periodicos.uem.br/ojs/index.php/ ActaSciHealthSci/article/view/7624/pdf. 